\title{
Sustainability: Its Adaptation and Relevance in Remote Area Housing
}

Rosemarie Rusch and Rick Best, (Bond University, Australia)

\begin{abstract}
Little consideration has been given to the context of housing in remote areas. It is important for the economic survival of many remote communities that appropriate and sustainable housing solutions are decided and implemented. This report examines housing at St Pauls, Moa Island in the Torres Strait, using site information, historical research and a review of cultural and geo-political factors to compare the current model with similar studies in selfbuild housing undertaken in the region between 1986 and 1992. It not only demonstrates tangible economic benefits, but also evaluates the environmental and social improvements which can be achieved with a re-examination of the existing model. It is important to consider the value of investing in policies and practices of sustainable development that can play a pivotal role in potential capacity building within such communities. Current land tenure policy means that families wishing to own their own homes must leave St Pauls, or build illegally. Economically they cannot establish businesses so must leave the island or remain on welfare. The result of this is an exponential increase in the cost of providing community housing and the associated increase in social and health stresses. Acknowledgement at a policy level of the links between social and emotional well-being, and 'Closing the Gap' initiatives, have the potential to offer a wide range of funding opportunities and innovative approaches to solving the housing crisis in remote Australia, if they can be implemented in an open and effective manner.
\end{abstract}

\section{Introduction}

There is a burgeoning desire in remote Australia for housing projects that involve self-build or individually directed outcomes in tune with residents' needs and aspirations, which are not only cost effective, but culturally and demographically appropriate. While many studies have been undertaken with regard to publicly funded community housing, little consideration has been given to the context of housing in remote areas, nor the whole of system approach, not just for indigenous communities but their non-indigenous neighbours. If future housing in these areas is to be appropriate and sustainable it is imperative that it is understood that housing in remote areas does not in any way resemble urban housing and there should not be a replication of urban models. This report examines remote area housing at the grass roots level and uses the village of St Pauls on Moa Island in the Torres Strait as a focus for discussion of the link between housing and social well-being, economic certainty and, ultimately, sustainability. It compares the current model with a similar study in self-build housing undertaken at Moa between 1986 and 1992.

\section{Overview}

\section{Foundations of Sustainability}

Housing for Health ${ }^{1}$ identifies a link between a healthy living environment, health and wellbeing, education and training, good governance, resources and continuing development review. The sustainability continuum is enhanced by the resilience of the community and their courage to pursue follow-on enterprise through knowledge and economic security.

\footnotetext{
${ }^{1}$ Housing for Health are projects undertaken by Healthabitat which are based on principles which include safety and healthy living practices.
} 


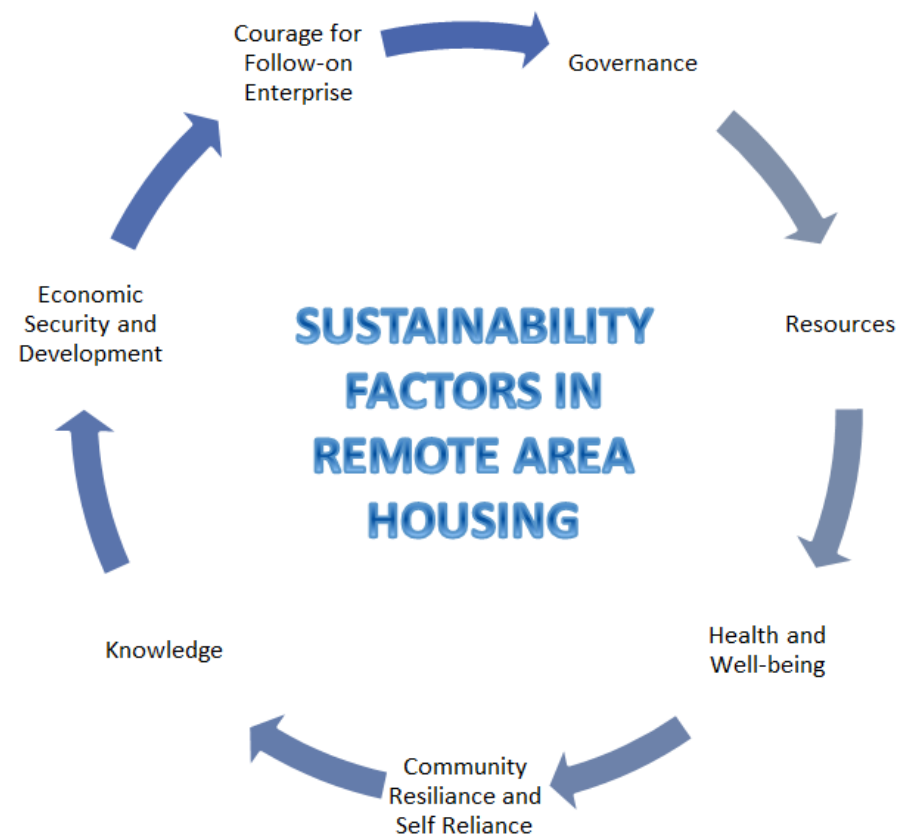

Figure 1 Foundations of stable, sustainable human settlement and development in Australian remote areas

Sustainability requires reconciliation of environmental, social and economic demands to harness the potential for long-term maintenance of human well-being. This is not as simple as providing a house. It is about a process of empowerment through inclusion and capacity building, which results in social transformation.

\section{Sustainable Design}

Sustainable design should relate to regional climate, soil conditions and cost effective building materials and technologies. Cultural aspects are also important as this affects the way people use buildings and their incorporated systems. The short lifecycle of housing in remote areas has proved to be a direct result of not considering the context of culture and environment in which they are constructed.

Evidence-based data collected by Housing for Health (Healthabitat, 2013) since 1987 to improve housing in Indigenous Australia initially showed that $80 \%$ of all problems were due to faulty construction, lack of supervision and lack of maintenance, dispelling the stereotypical view that vandalism was the cause. Well considered housing should draw upon community resources. Implementing a program of education and training releases the responsibility for maintenance of existing housing to the community, providing not only employment but also a sense of self-reliance while reducing the cost of uninterested fly-infly-out contractors.

\section{Remote Area Costs and Sustainability}

There is no doubt that distance directly affects the cost of construction. Apart from transportation of materials, the current practice of bringing in external labour at premium rates and the lack of competition in tender processes impose cost pressures which impact heavily on the number of houses that can be built within the allocated budget.

There may also be a reduced work season, due to inaccessibility during the wet season and high summer temperatures. These inhospitable conditions are not always reconcilable with the standard of housing constructed. Corrosion caused by heavy rainfall and high humidity 
in the tropics and sand and heat in the arid areas of Australia, coupled with overcrowding resulting from low housing availability, mean that sustainable design needs to address the robustness of materials if houses are to last in these environments. Meeting the triple bottom line (people, planet and profit) may mean initial increased expenditure in construction but substantially less expense in maintenance or replacement over time.

The triple bottom line (TBL) has been generally accepted as a measure of corporate social responsibility and aims to measure corporations' social and environmental, as well as financial performance over time. It works on the premise that only when a company produces a TBL is it taking account of the full cost of doing business. Arguably a succession of governments has not achieved a TBL balance when viewed in the context of health, happiness and employability that comes from self-help housing, particularly as demonstrated at St Pauls.

The National Partnership Agreement on Remote Indigenous Housing (NPARIH) (2009) was to establish a strategy to improve the poor standard of housing in remote Australia and address the high levels of overcrowding and homelessness, with the first phase intended to bring existing houses to a safe and habitable standard. The Agreement was also purported to ensure ongoing maintenance, infrastructure and essential support services as well as economic development opportunities through local training and employment in construction and housing management. It was hoped the Agreement would use housing as a platform for achieving targets in health, education and employment through improved living standards, and contribute to developing and maintaining sustainable communities in remote Australia. Whether this percolated through to the Torres Strait and Moa Island in particular, is questionable.

Inclusive, integrated planning is required in remote areas to improve construction processes. The current government policies are non-inclusive. Planning, design and funding are decided in boardrooms thousands of miles away with very little consultation and even less qualitative evaluation. To fully understand the implications one needs to be aware of just how remote some of these areas are. Moa Island is north of Bamaga, the furthest northern community on the tip of Queensland and is in the 'Very Remote' category in the Banks Channel of Torres Strait.

The topography is mountainous, with a near pristine biodiversity including rainforests, mangroves, reefs and plains. Moa Island has two villages, Kubin and St Pauls. In 2011 the population of Moa was estimated at 421 with approximately half living at Kubin and half at St Pauls. Of that population 95\% identify as Aboriginal or Torres Strait Islander.

\section{Logistics}

Construction costs on Moa are at least double those in Brisbane (Rawlinsons 2012). Transportation alone ${ }^{2}$ could justify this, however the cost of community housing in remote areas is considerably higher than this and patently unsustainable, not just in fiscal terms but also in terms of social and economic degradation. Established patterns of malaise across health, justice and incarceration, overcrowding and lack of employability or training associated with the limited options in community housing, make it imperative to reconsider alternatives in self-help.

\footnotetext{
${ }^{2}$ While there is air transport for smaller items, most provisions come by barge from Cairns once a week. If some of the locally available building materials could be used, not only would transportation costs be reduced but the economy of the island would be lifted and, with the resultant availability of jobs and community infrastructure, more economically sustainable.
}

Rusch, R and Best, R (2014) 'Sustainability: Its adaptation and relevance in remote area housing', Australasian Journal of Construction Economics and Building, 14 (1) 88-104 
Pholeros (2013a) estimates the cost of a single community house on the similarly remote Tiwi Islands north of Darwin to be in the $\$ 1$ million range, and that "money is simply not an

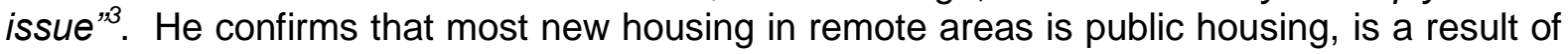
policies that are the product of often chaotic processes and is 'delivered' with little involvement of tenants or communities. He suggests that this lack of interaction is common for social housing and has been more evident since the introduction of the $2009 \mathrm{NPARIH}$, contrary to its own output benchmarks. ${ }^{4}$

If money is not an issue at present, then accountability for its mismanagement will surely become an issue in the future as a key indicator of unsustainable government practice. For the Australian legal and bureaucratic framework for remote area housing to become a worthwhile proposition it needs a coordinated effort on the part of Local, State and Federal governments to manage the system as a whole, rather than making decisions and funding projects independently within their own portfolios. One could contend that such participation is professionally threatening. Finding common ground means sharing authority and being accountable.

\section{Remoteness Scope}

Remote Australia is frequently portrayed as a series of dysfunctional Indigenous settlements and seen therefore as an 'Indigenous' issue. However it can be claimed this is a result of remoteness rather than cultural or racial divisions. Predominantly non-indigenous settlements in remote Australia suffer from similar issues. While this report is centered on Moa Island, it does so with reference to remote Australian housing as a whole and an ineffective and disengaged government response despite years of agreements with, and supplication from pastoralists, indigenous communities, health workers, educators and others who have an interest in working jointly to bring about the systemic changes needed.

Walker (2012) cites Fred Chaney ${ }^{5}$ who suggested that there is a social, ecological and economic crisis facing remote Australia as Australia's political and economic system serves the large number of people residing in urban Australia at the expense of remote Australians. This, Chaney suggested, will have significant consequences for the whole of Australia although most urban Australians are oblivious to it. Statistics (Walker, et al., 2012) show that $85 \%$ of our land mass contains only $11 \%$ of our population but produces more than $60 \%$ of our national wealth through mining, primary industry and tourism. Surely this should entitle people in these regions to better, fairer housing options and an opportunity to remain economically viable.

As Healthabitat (2013) has demonstrated, programs that focus on delivery of a physical product alone, such as housing, will not address issues of poverty and chronic illness in remote areas. Achieving change requires much more than the design of structure; it is about recognizing the potential in people to control and manage their own affairs and removing the obstacles and constraints of legislation which prevent them realising that potential.

\footnotetext{
${ }^{3}$ Pholeros is referring to money available under the National Partnership Agreement. His frustration is with the way the money is allocated and how little is directed where it was intended.

${ }^{4}$ This Agreement between the Commonwealth Government and individual State Governments and Territories (Council of Australian Governments) aims to facilitate reform with a ten year ( $\$ 5.5 \mathrm{bn})$ funding strategy to provide, among other initiatives, housing for Indigenous people in remote communities and to address overcrowding, homelessness, poor housing condition and severe housing shortage in remote Indigenous communities.

${ }^{5}$ Frederick Michael (Fred) Chaney, AO is a former Australian politician who, until April 2007, held the position of deputy chairman of the Australian Native Title Tribunal and is Chair of Desert Knowledge Australia and on the Board of Directors of Reconciliation Australia.
}

Rusch, R and Best, R (2014) 'Sustainability: Its adaptation and relevance in remote area housing', Australasian Journal of Construction Economics and Building, 14 (1) 88-104 


\title{
The Context of Place-making
}

Regardless of the diversity of locations, climate and conditions in Australia, housing delivery is homogenous; arguably lacking in relevance or any connection to the concept of placemaking.

Government and external professionals, perhaps well intentioned, provide recipients with little opportunity to obtain housing that is appropriate and meaningful to them.

\begin{abstract}
I think architects, engineers and administrators are taught to be clever with materials and technology, to make statements on art and society, and to solve and colonise the unknown. Whilst I like to think this preoccupation at times has its place, it has less relevance when working with Aboriginal and Torres Strait Islander peoples. Here we must have faith in and make real space for the creativity and lifestyle aspirations of dynamic communities of Indigenous Australians. They are not needy subjects of White benevolence but equal partners in the challenging times we have ahead. (Haar, 2000)
\end{abstract}

Architect Paul Haar was involved in a number of self-help housing projects during the 1980s and early 1990s, one of which was on Moa Island. What he found was that aspirations, logistics and processes varied enormously, not only between communities and regions but also between individuals and families within the Moa community.

Haar is considered a specialist in self-build remote area housing and his work on Moa over 20 years ago has provided a benchmark against which contemporary housing policy in remote communities can be compared.

Although the St Pauls community is regarded as a discrete indigenous community, this report is not about indigenous housing or anthropological or racial issues, rather it comments on tangible housing outcomes that might benefit and enhance remote communities. Research has shown that there is a common link between pastoralists, Aboriginal people and anyone else living 'out bush', expressed in their concern for their country, the land and the sea which sustain them (Walker, et al., 2012).

The cattle industry would not have succeeded without the active involvement of Aboriginal stockmen and their families. Sugar cane, a major export, would not have been possible without Islander and other immigrant labour and missionaries would not have survived without the support of the remote communities in which they were stationed. St Pauls men have served in wars, serviced remote lighthouses and since 1968 have held the record for railway track laying on the Port Hedland to Mt Newman railroad construction project. Islanders were described as tremendous workers, strong, willing, fast and efficient; men who were commended for their skill in handling the heavy rail, their fitness, their rhythmic team work and pride in their work (Newie, 2012). These qualities were evident in the people Haar assisted in the 1980s and is still apparent today. Yet they struggle to bring economic security to their island, for the right to self-determination and even to put a roof over their heads.

Housing procurement is not static. It is subject to the vagaries of globalisation, cultural intermingling and environmental and economic relationships. Within this dynamic framework, why then has remote area housing languished as is evident on Moa?

There is no place here for a 'one size fits all' approach which disregards the relationship between people and place-making. St Pauls is an evolving community and as such housing delivery needs to be divorced from mainstream architectural and construction theory and red tape. Instead of continuing to provide social housing at huge expense and encouraging a co-dependent relationship between government providers and passive remote area 
recipients, it may be prudent to explore more fully a policy of interdependence and participation, resilience and productivity as facilitated by Paul Haar on Moa more than 20 years ago.

From that allocated to the Torres Strait region out of the Government's $\$ 5.5 \mathrm{bn}$ (over 10 years) commitment to housing delivery, only one new house has been built at Moa in recent years (TSIRC, 2013). Based on Pholeros' estimation of $\$ 1 \mathrm{~m}$ per house this could be the full allocation for Moa for the foreseeable future. More definitive construction figures have been difficult to obtain from TSIRC as there has been no response to requests for information or clarification. This budget only takes into account 'provided' housing; it does not consider opportunities for home ownership which has in the past been restricted by:

- underlying community land tenure arrangements

- the high cost of construction in remote areas

- the absence of commercial lending and financial services

- low incomes

- a lack of education about home ownership

Despite the 20 year gap since Haar's work at St Pauls, this situation prevails.

\section{Settlement History}

\section{Population Statistics}

The St Pauls population is almost entirely descended from South Sea Islanders who were permitted to settle there after the forced repatriation of Pacific Islander labourers, following the Federal Government's introduction of The White Australia Policy in 1904. Permission to stay was based on age, the length of time they had been in the Torres Strait, marriage to Torres Strait Islanders (thought to have settled on Moa 1000-1500 years ago) or property ownership.

\section{Settlement Timeline}

The pearl rush which began around 1879 brought foreign seamen from the Pacific Islands, the Philippines, Europe, Indonesia, Malaya and Japan, and merchants from China and Sri Lanka. In 1872 islands within 60 miles of mainland Australia were legally annexed to Queensland. The remaining islands were annexed in 1879.

In 1885 the Government Resident Magistrate, the Hon John Douglas, stationed at Thursday Island, instituted a system of indigenous self-government which was revoked after his death in 1904 when the Queensland government placed Islanders under the Protector of Aboriginals, essentially an administrative policy of control over their lives and earnings.

Despite this, by 1911 the ethos at St Pauls was one of hard work and industry. The community was self-sufficient with individually owned homes, established gardens, a church and community boats. Island taxes paid for all island infrastructures. (Bell, 2012) The residents of St Pauls were not subject to the Torres Strait Island Act because missions were exempt from control. They held full citizenship rights including the right to vote. The community had a viable, successful and sustainable social and economic base.

By the 1930's St Pauls residents had become indigenous under legislation. They were required to contribute a percentage of their wages to their Island Welfare Fund, some of which disappeared in unexplained charges and taxes. A nightly curfew was instituted and travel passes were required for any movement off the island unless at the pleasure of the government. Community boats (and their associated profits) became government boats. 
In early 1936, a general strike by Islanders working the boats was instigated to demand freedom of movement, the right to run their own affairs, choice over where and with whom they could work, and better pay rates. It is believed to be the first organised Islander challenge to European authority, but gained little in real terms. Government still retained control of boats and wages. Nevertheless it was a further verification of the Islanders initiative and determination to work toward a better future.

In 1947 the first islanders were allowed to move to the mainland for work, beginning the post-war diaspora which halved the population and threatened island viability. It is debateable whether St Pauls has ever fully recovered from these policies either socially or economically. (Bell, 2012)

By the early 1980's when several extended families returned to Moa seeking a more traditional lifestyle to that on mainland Australia, St Pauls was officially classified as a Torres Strait Community. Politically this was seen as a step in the right direction. Unfortunately they were subject to the vicissitudes of unpredictable political manoeuvring where land tenure and self-determination were concerned.

\section{Land Tenure}

\section{Brief History}

St Pauls land leases, although locally registered since 1905, never existed officially and were replaced in the early 1970 by Permits to Occupy, which did not confer exclusive possession and were a means of producing revenue for the Lands Department, authorising (for a small fee) informal leaseholders to occupy land upon which they would otherwise be trespassing!

By 1984 the land status changed to a Deed of Grant in Trust (DOGIT) ${ }^{6}$ which was amended again in 1999 under the Native Title Determination to an Indigenous Land Use Agreement. This meant the people of St Pauls were now under a Native Title Prescribed Body Corporate with no individual ownership possible. (Bell, 2013b)

In 2008, with the creation of the Torres Strait Island Regional Council, under the Queensland Government amalgamation policy, jurisdiction of land has become a political 'hot potato'. Buying or building a home on communal land is simply not an option unless land tenure is secure.

\section{Moa Land Tenure Status 2013}

Legal information obtained in February 2012, qualified as being neither advice nor legal opinion, (Bell, 2013a) acknowledged that Historic Title exists in St Pauls, but dealing with it is problematic as it has no legal status under any legislation. It appears that individual land holdings, leases and grants have evaporated. Currently owners who have built their own houses don't own the land or have leases, and can neither raise finance for mortgages nor get insurance. While the Australian Government's Indigenous Business Australia offers loans to buy or build on communal land, the policy is somewhat restrictive. To be eligible, the community must first have been assessed and accepted as a location in which the program is to be made available and then, only if land tenure and administrative

\footnotetext{
${ }^{6}$ A Deed of Grant in Trust (or DOGIT) is the name for a system of community-level land trust established in Queensland allowing community councils to be created and to own and administer former reserves or missions. These Incorporated Aboriginal Councils have the power to pass by-laws, appoint police for the community, and are responsible for maintaining housing and infrastructure, running the Community Development Employment Program and issuing hunting, fishing and camping permits. They work much like local government, but are different in that they own the land they administer on behalf of the community.
} 
arrangements are in place (IBA, 2013). This clearly does not apply to St Pauls and as at March 2013 the IBA has not extended its program to the Torres Strait region.

The dearth of good integrated (and hence sustainable) decision making within the public service, without considering cross-disciplinary impacts, has undoubtedly contributed to the mayhem surrounding land tenure in remote Australia.

In terms of housing it is imperative to progress land tenure policy because there is more at stake. Council of Australian Governments (COAG), National Affordable Housing Agreement (NAHA) and National Partnership Agreement on Remote Indigenous Housing (NPARIH) need this resolution in order to facilitate home ownership opportunities, thereby generating a means of transferring the responsibility for housing to the community and allowing governments to be seen to be facilitating social wellbeing while concurrently meeting their own economic efficiency goals. As policy currently stands, finance for home ownership is only available in economically sustainable communities, leaving the onus on governments to continue funding community housing provision and maintenance for a much longer term.

If Fred Chaney's predictions are correct, home ownership will never be possible; communities already struggling will no longer be economically viable. In summary, on Moa:

- There is no land available to build on which is not Crown land

- Where there is land title it is a DOGIT therefore home loans are difficult to obtain

One of the main objectives for economic development in the Torres Strait region was to ensure resolution of land tenure issues so that there is sufficient land available for economic development opportunities and that this will mean housing options for both affordable ownership and community rental are addressed. Regrettably this target has not been met.

\section{Architectural History}

The Early Years

The roots of self-build housing began with early settlement at Moa. Like many of the other settlements in Australia, Moa homes were constructed of logs, bark, grass, leaves and bamboo, depending on the available materials in a particular area, which were adopted and assimilated to construct substantial thatched roof stilt houses. Mangrove and Bloodwood were also used, particularly with mission buildings. The Islander's homes emphasised external living with social interaction for activities such as cooking and eating, while environmental factors influenced the design and setting. The houses were sited, designed and built by the occupants.

\section{The New Order}

Ecological degradation and the resultant species protection policy make it unlikely that timber could now be legally harvested for construction on Moa, although this resource was still available during the 1980s. Haar (Haar, 1992) recommended the establishment of a forestry program and possible sawmill to provide building timber for future generations. No indication of implementation is evident, although there is sufficient land available and this could still be a viable and sustainable industry with venture capital and policy review. There is already a CDEP Ranger Program in place for environmental management of this resource.

Moa Islanders, like many others in remote Australia, are a dynamic and self-reliant community in a continual process of change. Their homes are not merely shelters but also a means of self-expression, reflecting the needs of family, tradition and social patterns. As Haar discovered, contemporary remote area housing aspirations at Moa are not necessarily based on the Melanesian or Pacific Islander culture from which they originated. Traditional materials such as bamboo and woven palm were by the 1980's considered inadequate and 'proper solid' housing such as mud brick and stone was favoured (Haar, 2000). 
Through a process of political and religious change, as well as the migrations to the mainland and back, both imposed and voluntary, many people now lean towards a more 'western' housing ideal. This should not necessarily be construed as wanting community provided housing.

\section{Social Cohesion and the Self Help Model}

Similar to the situation described for Cape York, in the words of Noel Pearson (Pearson, 2009) "they want a hand up, not a hand out".

Haar recognized that housing in the Torres Strait was dependent on external forces with little input from Island people. Disregarding the cost of imported building materials and labour, he expressed concern at the long term social costs, believing the process contributes to a loss of interest and skills for expression shown by their grandparents as members of a selfsustaining community (Haar, 2013). Interviews and observations carried out in 2012 showed this to be a continuing and valid concern. Many of the following generation are content to accept community housing while their parents and elders struggle to understand the loss of status of their Historic Title in St Pauls community and the resultant difficulty in securing home ownership.

Haar presented self-build housing as one alternative for many communities whose access to a fragmented and failing housing delivery system was limited at best. He does not suggest that it is suitable for all and discusses both the advantages and disadvantages in detail (Haar, 1992). It is interesting to note that his time at Moa and other remote communities was during a period of groundswell movement in Australian self-build housing. Individuals across the country, following the ideals of Alistair Knox, GF Middleton and others, started to consider alternative building techniques, particularly mud brick. While for Knox this had been philosophically driven, for most it was a resistance and determination driven by financial necessity or an anti-establishment agenda. In remote pockets, away from official reach, self-build houses were established using whatever materials were available with scant regard for building permits. In Kuranda (North Queensland) for example, the practice was so widespread that by the 1990's the Mareeba Shire Council was forced to offer amnesty, in an attempt to track down and 'approve' these homes. While this was a beneficial and desirable outcome for the owners, it also provided Council with a dramatic increase in rates collection without the need to include additional services or infrastructure.

Haar's experience at St Pauls was similar and sadly the situation has not improved in the intervening years. The self-build housing he facilitated was undertaken by families with little choice but much determination and hard 'yakka'. Unrelenting resistance from QBuild, the government building contractors, their financial position and low priority in the housing delivery line meant they initially built their houses with no permits.

All levels of Australian government must recognise the importance of ensuring remote area communities such as St Pauls can access the necessary resources to meet their basic needs, as well as being given opportunities to use, develop and retain their resources in ways that will improve their quality of life and their cultural, social and economic development, as promised in the plethora of policy reforms on housing and homelessness in remote areas. Progress has been made however none come to mind in recent years at St Pauls that encourage community participation, nor adapting the construction methodology to suit the workforce skills or passing those skills on to the next generation. The mediocrity of public service decision making, without consideration of social and locational logistics has only exacerbated the problems of remote area housing, both community and self-help. 


\section{Available Resources}

\section{Building Materials}

A number of building materials are readily available at Moa, but for a variety of reasons they are not being utilised. It is not the purpose of this report to describe building materials in detail, merely to confirm that there are abundant resources available which need to be explored in an attempt to offer alternative pathways to housing procurement, whether selfhelp or community housing. Potential materials include:

- Granite (abundantly available and currently used for decorative purposes)

- Bloodwood, Mangrove

- Bamboo

- Concrete masonry block

- Recycled plastic from ocean borne debris

- Clay (Clay pits previously used by Haar and others for mud brick making)

While it is reasonable to conclude that some materials are finite in supply or impractical for intensive harvesting, several others could be beneficial in the long term.

\section{Timber}

Certainly there is no suggestion that timber stocks should be depleted, but there is room for continual improvement in sourcing and studying available construction materials and building technologies as part of the procurement process, while examining affordable alternatives.

Despite Haar's recommendation for a forest management program in the late 1980's, little progress has been made to implement a forest industry and the situation has been further complicated by overlapping government policy under the 'Caring for Country' and 'Conservation Management' banners.

Mangrove is further protected because of its importance to fisheries and the marine ecosystem. The Mangrove Watch Program (Mangrove Watch Ltd, 2013) monitored and analysed by James Cook University, is not restricted to monitoring of mangroves but encompasses the whole shoreline and promotes better management and conservation of tidal and freshwater wetlands. If Moa is to maintain the existing near pristine marine biodiversity these studies are extremely important. Anecdotal evidence suggests however that when money is scarce for building materials the islanders still harvest from the back of Moa "where no-one can see". Frustrated by lack of progress in reducing overcrowding and homelessness, it seems that desperate times lead to desperate measures, which will not be sustainable in the long term. Without research into the viability of a forest harvesting program, conflict between housing needs and conservation will remain.

\section{The Bamboo Factor}

Bamboo forests are extensive on Moa but are severely overgrown and there is uncertainty about this species' suitability for structural use. While not advocating that this resource is a major building material, with the current trend towards renewable resources and innovative material science studies into bamboo uses, it is unquestionably worth future consideration.

The current impediment to bamboo use in relation to construction at St Pauls is that the plantations need to be re-invigorated and studies undertaken into the efficacy of the species and its uses. Aided by better road access, the study could be incorporated into the existing Ranger or CDEP programs and provide subsequent regional employment. Should research show this species not to be of a structural quality there are many other uses for this renewable resource which could contribute to the economy of St Pauls in the long term. The plantation in its current state is of little benefit to the community. 
The Torres Strait islands have many advantages over other remote communities. The sewer system was upgraded in 2009 and St Pauls is well serviced with reticulated water, water tanks and power. In keeping with the objectives of TSIRC commitment to economic development, CDEP workers were up-skilled during the sewer system upgrade and transitioned to full time employment. However other projects have not benefitted the community in the same way.

\section{Concrete Block}

A concrete masonry block plant once supplied Moa and most of the outer islands but has been closed since the amalgamation of Councils in 2009. With willing local government agreement and an injection of venture capital this plant could provide jobs and reduce the cost of importing building materials to some degree.

Granted, concrete block is not viewed by architects as appropriate for tropical design, where lightweight, low mass materials are recommended, however if supply of building materials remains a major issue (and it has proven to be so) then there is some merit in pursuing the commercial viability of this resource.

When considering key design responses in remote communities as suggested by the Australian Housing and Urban Research Institute (Fien, 2008), concrete block certainly doesn't meet all of the criteria. It is probably not culturally appropriate or eco-efficient however it is possible that if it could be made readily available it may fulfil the criteria for employment opportunities, life cycle costing and procurement.

Simple construction materials such as blockwork may be suited to the community workforce and their attraction towards solid construction is not necessarily a bad thing if it brings home ownership within the reach of families through better affordability. Blockwork is also durable and cyclone resistant. Individual owners are perhaps best placed to decide the homes they want.

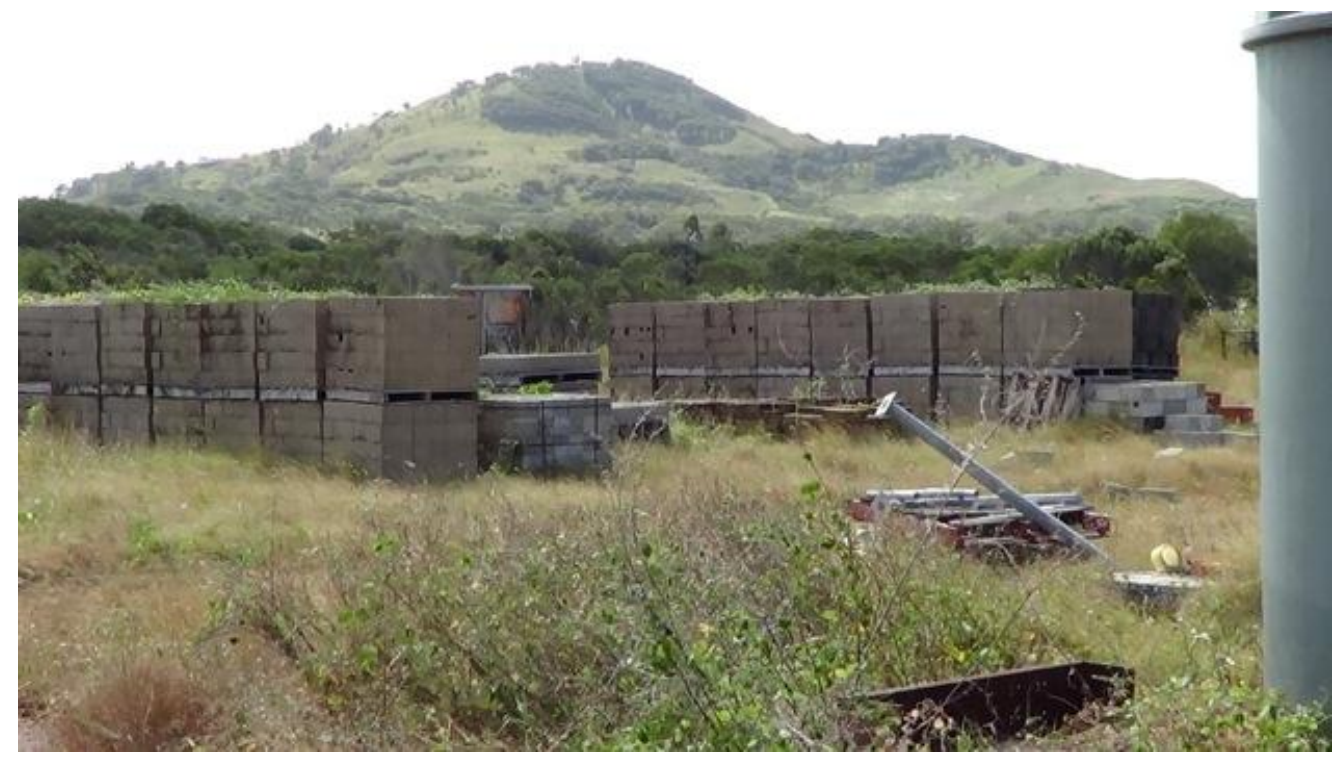

Figure 2 Blocks from abandoned plant, a forlorn and neglected resource

Rusch, R and Best, R (2014) 'Sustainability: Its adaptation and relevance in remote area housing', Australasian Journal of Construction Economics and Building, 14 (1) 88-104 


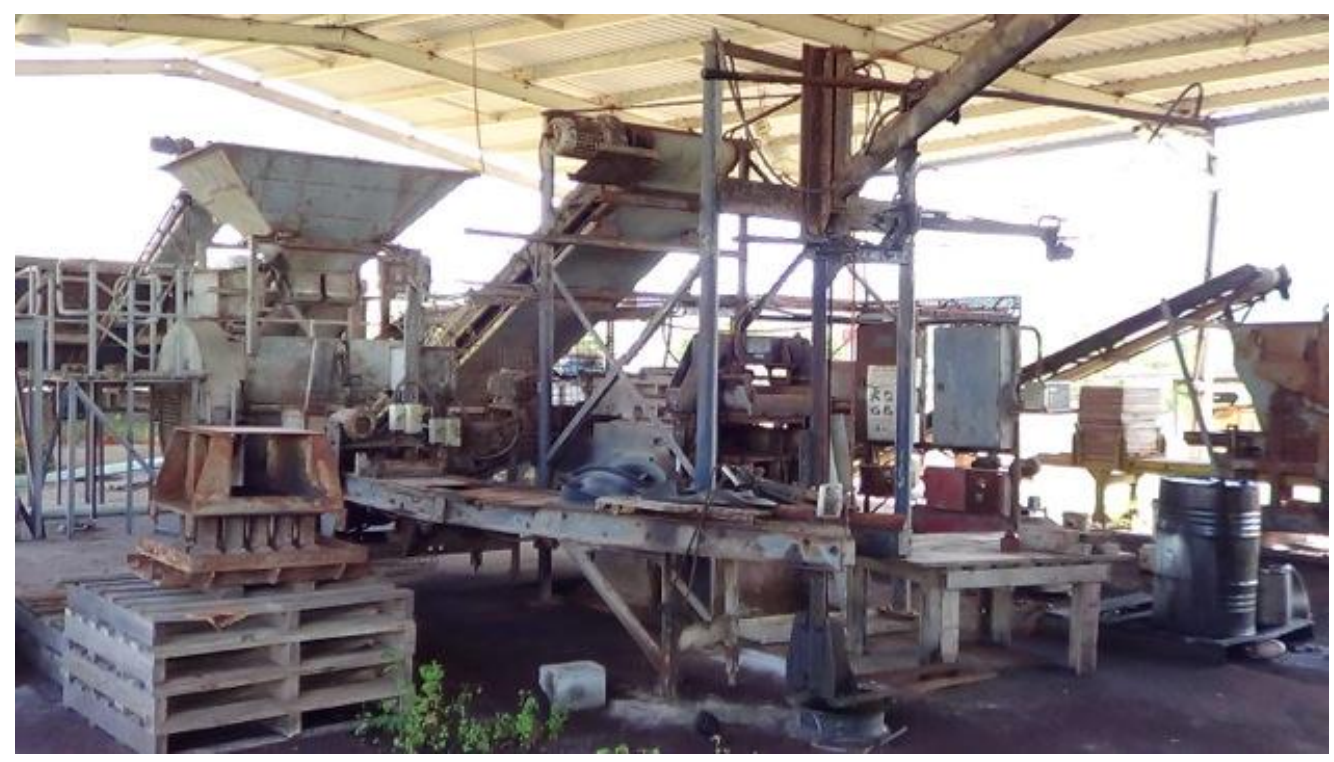

Figure 3 Abandoned block plant has fallen into disrepair

\section{Ocean Borne Debris}

In the case of ocean borne debris, a potentially unlimited renewable resource could be explored for future economic benefit to the community, with the dual benefit of protecting the environment and valuable bio-diversity of the Torres Strait region. Observation has shown that most of the debris washed up daily on St Pauls' beaches is plastics from foreign shipping, is of a large quantity and is becoming an increasing problem for the local community in terms of refuse collection and disposal.

\section{Muddy Waters}

Mud bricks are the ideal building material from an environmental perspective and are a forgiving construction medium. They are also cheap. The use of earth construction is well established in energy efficient housing.

There don't appear to be any restrictions on the use of mud on Moa other than the hard graft required in production and the fact that there is little incentive for the next generation of young people to bother. Most were babies during the time Haar was on Moa. Many have been away to Thursday Island or mainland Australia for higher education and have loftier expectations. They have no desire or motivation to build because they can see no actual benefit to themselves in doing so therefore the requirement for manual labour or 'sweat equity' is of absolutely no interest to them.

The innovative possibilities for self-help housing promulgated by their parents are anathema to the next generation. It is far easier to take social housing with no responsibility for initial outlay or future maintenance if there is no certainty of ownership in any case. Thus the status quo prevails and desire for action is cauterised.

American economist Milton Friedman suggested there were four types of cash, the spending results of which were dependent on the source and user of the cash. I would suggest that his third type of cash applies in regard to the attitude toward community housing on Moa at present:

I can spend somebody else's money on myself. And if I spend somebody else's money on myself, then I'm sure going to have a good lunch! (The American Spectator, 2011) 


\section{Cost Planning}

Prime Ministers Report

The Federal Government claims to have exceeded targets for home refurbishment (FaHCSIA, 2013). While the reported targets are Australia wide, with regard to the Torres Strait and Moa Island in particular, no figures have been made available against which to measure success. As previously stated only one house has been constructed on Moa in recent years. There are no immediate plans for more and no mention was made of refurbishment. This is not to suggest that nothing is being done, merely that there is little evidence to support the government's claim, and no way of measuring outcomes.

As early as 2007 Healthabitat (Pholeros, 2013) queried inconsistencies between expenditure and outcomes in remote area housing. Pholeros casts doubt on the gap between the stated budget and the program scope since the inception of the NPARIH. Alarmingly he suggests that there is no information about where the money is going and that the program is proceeding with scant regard for evidence based solutions. His response to the publicly stated budget is detailed on the Healthabit website and can be summarised as follows:

- If administration and overhead costs were $8 \%$ (as originallty stated) the budget should have been $\$ 3,478,680,000$

- The published budget was $\$ 5,475,700,000$ suggesting that administration and overhead costs were actually $70 \%$ (Healthabitat, 2013)

Pholeros questions whether it is possible that fees and charges have been raised to $70 \%$, when the original agreed cap was $8 \%$ and why there seems no correlation with the national programmed budget. Success is contingent on transparency and accountability or we will have yet another vexing housing delivery model. The above figures are food for thought. Pholeros does qualify his calculations as having insufficient information but one would have to ask - why the secrecy? In this instance perhaps Friedman's fourth type of cash applies.

I can spend somebody else's money on somebody else. And if I spend somebody else's money on somebody else, I'm not concerned about how much it is, and I'm not concerned about what I get. (The American Spectator, 2011)

\section{Regional Employment}

Pholeros is also cautious about the employment figures claimed. Clearly if only $30 \%$ of the construction workforce is indigenous (FaHCSIA, 2013) this is still well below the Healthabitat recommended figure of $78 \%$. He is far less optimistic and contends that there are places where undertaking a safety course was counted as employment (Pholeros, 2013).

The Torres Strait Regional Authority asserts that it follows these employment objectives (TSRA, 2013) however discussion with the CDEP workers at Moa suggest that they are rarely included in any construction work or transitional training.

Lack of due process will only contribute to incremental dependence-inducing behaviour and displacement from community. Unless some tangible economic benefits can be gained in terms of mainstream employment, migration of adolescents and families to the mainland for education and jobs will once again change the demographic of St Pauls. Only the ageing will remain, wealth and income will go to the mainland, and Centrelink will continue to be the dominant economy on the island. This renders home ownership and self-builds all but impossible regardless of incentives. 


\section{Housing Alternatives}

Self-help

During Haar's time at Moa the self-help housing approach brought home ownership within the reach of families who were prepared to work hard. He introduced simple construction methods suited to the community workforce and respected their attraction towards a more local and traditional building culture using bush materials that were readily available.

An effective ownership strategy means allowing people who can be involved to believe that what is being offered has the potential to make a difference in their lives. Progress in the intervening years has meant that the self-build model has foundered, in the main due to land tenure and funding restrictions. But the desire for a self-help model has intensified and fanned the remaining coals of persistence.

Reflections on the issues confronting St Pauls residents in terms of a habitable home show that despite the competing imperatives of economic survival and social cohesion, pockets of resourceful independence simmer.

Several islanders, tired of waiting and confronted by antagonistic public servant interventions have "just built" regardless of land tenure, building permissions or finance. Unimpeded by perceived legal barriers and knowing that there would be scant assistance from government at all levels they were faced with the choice of leaving the island to pursue work and a home of their own or go down the self-procurement path by whatever means possible. While researchers and governments talk of design frameworks and culturally appropriate housing, such lofty ideals are a long way off for the people of St Pauls. Any modest shelter is better than none at all. Tired of the rhetoric and hollow promises, they have chosen to get on with unfettered implementation.

Having already passed retirement age, the chances of gaining employment off the island was not an option for this group and in any case, family ties mean they want a place where their grandchildren can return to during school holidays or "if they get into trouble".

\section{New Technologies}

There have been many innovative advances in technology, in particular in regard to construction, which are markedly more cost effective than the methods government is currently employing on community housing. Mining camps and cattle stations for example face similar issues of remoteness and yet they can construct in record time and (because they have to be competitive and accountable) for much less cost. It appears that taking the word 'Indigenous' out of the remote area housing equation is synonymous with more affordable housing. Mining companies in Darwin are purchasing fully fitted out transportable three-bedroom houses for about $\$ 200,000$ (Armbrust, 2012). While the total cost may be more than that for housing in urban areas it is reasonable considering the context in which it is required and far less than the $\$ 1$ million per house the government is currently spending.

There are innumerable building groups that have developed innovative construction technology which delivers housing by significantly faster, more economical and more sustainable methods. Pre-fabricated building solutions, suitable for a wide variety of remote housing construction projects, are able to be delivered in up to half the time of traditional methods of construction with significant cost savings and higher quality finished products. Competitive private enterprise means that most systems can adapt to the specific design features of any given project, as well as flat pack delivery suitable for community labour to erect. This flexibility allows collaborative and adaptive solutions, which is the key to underpinning partnerships and cultivating a sense of belonging and responsibility. A million dollars spent supporting private housing would save many more millions on community housing expenditure and give islanders accountability for their own objectives. 
Innovative and intensive approaches are needed to bring about the major shift in motivation that might energise self-help housing. One could conclude that the main impediment seems to be the relentless interventions of successive adversarial government departments who seem unable to 'close the deal'.

\section{Conclusion}

There is a quirky expression in remote areas which encompasses a myriad of meanings. 'Which way?' can mean 'how are you' or 'what's up' or 'where are you going' but is also a combination of all of the above; a way of confirming that everything is OK. So, 'which way' for remote area housing policy?

Acknowledgement at a policy level of the links between social and emotional well-being, and 'Closing the Gap' initiatives, have the potential to offer a wide range of funding opportunities and innovative approaches to solving the housing crisis in remote Australia. Breaking down departmental boundaries and giving existing community housing tenants, and those that have self-built the option to take ownership of the homes they live in, would contribute to ending welfare dependence if bureaucracies moved away from their own agendas for 'social' housing. Supporting private housing also supports economic stimulation of communities, which are more than capable of making their own decisions. It is evident that there are only three obstructions to achieving this:

- lack of secure land tenure

- lack of economic security

- difficulty of marshalling political will

The land tenure impediments at St Pauls inhibit the residents' ability to be independent and earn a living. There is sufficient evidence to suggest that they legally purchased their land as early as 1905. Through a series of governmental policies this ownership was erased. It's time the inequity was redressed and land tenure was granted, preferably at no cost. Where family lands are mapped, as has already been proven in St Pauls, there should be no deterrents to transferring the leases out of the DOGIT and into private ownership along traditional lines and inheritance agreements that already exist. Community housing tenants should be given the choice of ownership of the houses they live in at no cost (and of course the responsibility for future maintenance), or a sliding scale of purchase, particularly if they have been paying rent on those houses for longer than five years. The majority of the community houses at St Pauls are old and 'tired' and many of them have long passed their life cycle replacement value.

The intractable problems of land ownership at Moa are the result of legislative and administrative arrangements that should have played no part in the lives of these Islanders. It was their land to start with and should now be returned.

Currently, families wishing to own their own homes must leave St Pauls, or build illegally. Economically, for similar land tenure reasons, they cannot establish businesses so must leave the island or remain on Centrelink. The thrust of this is an exponential increase in the cost of providing community housing and the associated increase in social and health stresses. Encumbrances such as these contribute to the malfunction of place and a loss of social cohesion and self-esteem.

The St Pauls community has spirit and grit. Prior to what amounted to little more than theft of their land and their freedoms in the early 1900s, St Pauls was a thriving, self-reliant community and it could be again, with a modicum of competent leadership from politicians. Is there any point in investing huge amounts of money on community housing that people can feasibly build better and more cheaply for themselves? Give them the building blocks of 
land tenure, skills training, self-build opportunity and access to affordable finance. These basic requirements are no different to what is readily available in urban areas of Australia. With a population of just over two hundred at St Pauls, and existing historical maps of family allotments, this should not be difficult to implement.

With all that is wrong, what is the direction for a solution, and what might that look like? Or is it an insoluble dilemma?

\begin{abstract}
After years of lobbying, meetings, summits and conferences, the Australian Government's Department of Families, Housing, Community Services and Indigenous Affairs in March 2013 endorsed a further paper to 'explore' available information and 'identify' opportunities in housing and broader policy (FaHCSIA, 2013)
\end{abstract}

What part of the previous thirty years or more of research, reports, reviews and gnashing of teeth have they not understood?

\title{
References
}

ABS, 2013. National Regional Profile Torres Strait. [Online] Available at: http://www.abs.gov.au/ausstats/abs@nrp.nsf/lookup/LGA36960Main+Features12007-2011 [Accessed 20 July 2013].

AIQS, 2003. Australian Cost Management Manual. Evaluation of Sustainable Development. 1st ed. Canberra: AIQS.

Armbrust, N., 2012. AUSCO Homes, Personal Interview [Interview] (November 2012).

Bell, H. R., 2012. St Paul's Story. Smythesdale: Unpublished.

Bell, H. R., 2013a. Notes from conversation between HRB and Chris McLaughlin. St Paul's: Unpublished.

Bell, H. R., 2013b. Personal Communication [Interview] (January - August 2013b).

FaHCSIA, 2013. Closing the Gap Prime Minister's Report, Canberra: Department of Families, Housing, Community Services and Indigenous Affair.

Fien, J. e. a., 2008. Towards a Design Framework for Remote Indigenous Housing, Melbourne: Australian Housing and Urban Research Institute.

Haar, P., 1992. Housing in the Torres Strait Region Towards a Self-Help Approach, Thornbury, Victoria: Paul Haar.

Haar, P., 2000. A Self-help Approach to Remote Area Housing, St Paul's Village, Moa Island, Torres Strait. 1986-92, In: P. Read, ed. Settlement: A History of Australian Indigenous Housing. Canberra: Aboriginal Studies Press, pp. 221-233.

Haar, P., 2003. Community Building and Housing Process Context for Self-Help Housing. In: P. Memmott, ed. Take 2 - Housing Design in Indigenous Australia. s.l.:Royal Australian Institute of Architects.

Haar, P., 2013. Personal communication [Interview] (June-August 2013).

Healthabitat, 2013. Healthabitat. [Online] Available at: http://healthabitat.com/bigissues/where-is-the-money-going [Accessed June-Aug 2013].

IBA, 2013. Buying a Home on Communal Land. [Online] Available at: http://www.iba.gov.au/home-ownership/buying-a-home-on-communal-land/] [Accessed 21 July 2013].

MacKellar, D., 1908. My Country. London: Official Dorothea MacKellar Website.

Mangrove Watch Ltd, 2013. Mangrove Watch Torres Strait Regional Authority. [Online] Available at: http://www.mangrovewatch.org.au/ [Accessed 2013].

Newie, G., 2012. Moa Island elder, Mt Newman railway track worker - Personal Communication [Interview] (February 2012).

Rusch, R and Best, R (2014) 'Sustainability: Its adaptation and relevance in remote area housing', Australasian Journal of Construction Economics and Building, 14 (1) 88-104 
Newie, M., 2012. Moa Island elder - Personal Communication [Interview] (February 2012).

Pearson, N., 2009. Up from the Mission. Brisbane: Black Inc.

Pholeros, P., 2013. Personal communication [Interview] (19 June 2013).

Pholeros, P., 2013. Personal Communication [Interview] (2 August 2013).

Rawlinsons, 2012. Australian Construction Handbook. 30 ed. s.l.:Rawlinsons Publishing.

The American Spectator, 2011. Friedman's Four Ways. [Online] Available at: http://spectator.org/archives/2011/10/05friedmans-four-ways [Accessed 5 August 2013].

TSIRC, 2013. Annual Report 2011-2012, Thursday Island: Torres Strait Island Regional Council.

TSRA, 2013. Torres Strait Development Plan 2009-2013, Thursday Island: Torres Strait Regional Authority.

Walker, B. W., Porter, D. J. \& Marsh, I., 2012. Fixing the Hole in Australia's Heartland: How Government needs to work in remote Australia, Alice Springs: Desert Knowledge Australia. 